\title{
BISMARCK
}

\section{SOME SECRET PAGES OF HIS HISTORY}

\author{
BEING A DIARY KEPT BY \\ DR. MORITZ BUSCH
}

DURING TWENTY-FIVE YEARS' OFFICIAL AND PRIVATE INTERCOURSE WITH THE GREAT CHANCELLOR

\section{IN THREE VOLUMES}

VOL. I

London

MACMILLAN AND CO., Limited

NEW YORK: THE MACMILLAN COMPANY

1898

All rights reserved 


\section{CONTENTS}

NOTE 3

PREFACE 4

CHAPTER I. MY APPOINTMENT AS AN OFFICIAL IN THE FOREIGN OFFICE, AND MY FIRST AUDIENCE WITH BISMARCK - WORK AND OBSERVATIONS UP TO THE OUTBREAK OF THE WAR WITH FRANCE .

CHAPTER II. DEPARTURE OF THE CHANCELLOR FOR THE SEAT OF WAR - I FOLLOW HIM, AT FIRST TO SAARBRUECK - JOURNEY FROM THERE TO THE FRENCH FRONTIER - THE FOREIGN OFFICE FLYING COLUMN

CHAPTER III. FROM THE FRONTIER TO GRAVELOTTE ......70

CHAPTER IV. COMMERCY - BAR LE DUC CLERMONT EN ARGONNE. 90

CHAPTER V. WE TURN TOWARDS THE NORTH - THE CHANCELLOR OF THE CONFEDEEATION AT KEZONVILLE - THE BATTLE AND BATTLEFIELD OF BEAUMONT

CHAPTER VI. SEDAN - BISMARCK AND NAPOLEON AT DONCHERY

CHAPTER VII. FROM THE MEUSE TO THE MARNE 136

CHAPTER VIII. BISMARCK AND FAVRE AT HAUTEMAISON - A FORTNIGHT IN ROTHSCHILD'S CHÂTEAU

CHAPTER IX. THE JOURNEY TO VERSAILLES MADAME JESSE'S HOUSE, AND OUR LIFE THERE ......185 
CHAPTER X. AUTUMN DAYS AT VERSAILLES.

CHAPTER XI. THIERS AND THE FIRST NEGOTIATIONS FOR AN ARMISTICE AT VERSAILLES

CHAPTER XII. GROWING DESIRE FOR A DECISION IN VARIOUS DIRECTIONS.

CHAPTER XIII. REMOVAL OF THE ANXIETY RESPECTING THE BAVARIAN TREATY IN THE REICHSTAG - THE BOMBARDMENT FURTHER POSTPONED

CHAPTER XIV. THE PROSPECTS OUTSIDE PARIS IMPROVE

CHAPTER XV. CHAUDORDY AND THE TRUTH OFFICERS OF BAD FAITH-FRENCH GARBLING THE CROWN PRINCE DINES WITH THE CHIEF.

CHAPTER XVI. FIRST WEEK OF THE BOMBARDMENT .....336

CHAPTER XVII. LAST WEEKS BEFORE THE CAPITULATION OF PARIS................................................361

CHAPTER XVIII. DURING THE NEGOTIATIONS RESPECTING THE CAPITULATION OF PARIS 385

CHAPTER XIX. FROM GAMBETTA'S RESIGNATION TO THE CONCLUSION OF THE PRELIMINARIES OF PEACE 


\section{NOTE}

The English edition of Dr. Busch's work which we publish to-day has been translated from the original German text in the possession of the publishers. A few passages have, however, been omitted as defamatory, or otherwise unsuitable for publication. Dr. Busch contemplated incorporating bodily in the first volume a reproduction of his earlier work: Prince Bismarck and his People during the Franco-German War; but while the many valuable additions which he made to it have been preserved, such portions as would no longer have presented any special interest for English readers have been considerably abridged. 


\section{PREFACE}

The work which I now present to the German people contains a complete ${ }^{1}$ account of all the events of which I was a witness during my intercourse of over twenty years with Prince Bismarck and his entourage. Part of it is not entirely new, as I have embodied in it portions of the book published by me in 1878, under the title: Prince Bismarck and his People during the Franco-German War. I have, however, restored the numerous passages which it was then deemed expedient to omit, and I have also dispensed with the many modifications by which, at that time, certain asperities of language had to be toned down. The bulk of the present work consists of a detailed narrative of the whole period of my intercourse with the Prince both before and after the French campaign. I collected and noted down all these particulars respecting Prince Bismarck and his immediate supporters and assistants, in the first place for my own use, and secondly as a contribution to the character and history of the Political Regenerator of Germany. The sole object of he diary which forms the basis of this work was to serve as a record of the whole truth so far as I had been able to ascertain it with my own eyes and ears. Any other object was out of the question, as it was impossible that I could desire to deceive myself. Subsequently, when I thought of publishing my notes, I was fully conscious of my responsibility towards history, the interests of which could not be promoted by material that had been coloured or garbled for party purposes. I wished neither to be an eulogist nor a censor. To my mind, panegyric was superfluous, and faultfinding was for me an impossibility. A tendency to the sensational is foreign to my nature, and I leave the pleasure to be derived from grand spectacular shows to lovers of the theatre. I desired to record the mental and other characteristics which our first Chancellor presented to me under such and such circumstances, thus helping to complete, and at times to rectify,

\footnotetext{
${ }^{1}$ Strictly speaking, almost complete, as some passages must still be omitted for the present.
} 